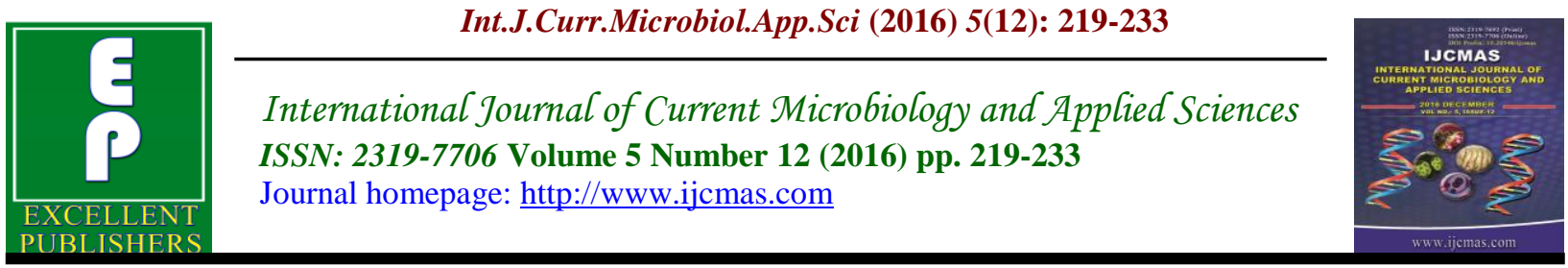

Original Research Article

http://dx.doi.org/10.20546/ijcmas.2016.512.024

\title{
Bioindices of Bacterial Communities
}

\author{
D. Sandhya Deepika* and K. Laxmi Sowmya \\ Department of Botany, Andhra University, Visakhapatnam- 530003, Andhra Pradesh, India \\ *Corresponding author
}

\begin{abstract}
A B S T R A C T
Keywords

Drinking water,

Quality

assessment,

Bioindices,

species

diversity.

\section{Article Info}

Accepted:

12 November 2016

Available Online:

10 December 2016

The bacterial study is a very useful tool for the assessment of water quality in any type of water body and also contributes to understanding of the basic nature of the aquatic system. An overview is given of the different indices for all available water sources present in the 10 different panchyaths of Ananthagiri mandal. The most commonly used indices are based on the estimation of relative abundance of species in samples. Relative abundance can also be used for either a graphical or a mathematical representation of species-abundance relationships, from which diversity indices can be deduced as well. Bioindices of species diversity can be derived from species counts, which are species richness (Margalef index, Menhinick's index), species evenness/dominance (Simpson index) and a combination of richness and dominance (Shannon-Wiener index), Pielou's evenness index (E), Berger-Parker dominance index is the number of individuals in the dominant taxon. Valasi Panchayth (Bore and well water samples) were polluted rest water samples were unpolluted regarding the quality of water. Thus we can use this study for the assessment of the water and to resolve the hygienic problems of the water.
\end{abstract}

\section{Introduction}

Diversity indices can serve as a good indicator of all pollution of water. Bioindices of species diversity can be derived from species evenness/dominance (Simpson index) and a combination of richness and dominance (Shannon-Wiener index) (Sigee, 2004). These diversity indices have been developed by taking into account the number of species and their relative abundance, which means the higher the value of these diversity indices, the more the oligotropic state of water bodies. For example, in the Simpson index, the possible range of value are between 0 and 1 , where values near 0 indicative of the least evenly distributed communities and values nearing 1 are indicative of the most evenly distributed communities, those approaching maximum diversity (non-polluted sample). The index represents the probability that two individuals randomly selected from the sample belong to different species.

\section{Materials and Methods}

In the present study, water samples were collected from three sources i.e., a well, a hand pump and stream once in a month for a period of 24 months from April 2011 to March 2013, in white plastic bottles, which 
were previously rinsed with distilled water and sterilized with $70 \%$ alcohol. At the collection point, the containers were rinsed thrice with the sample water before being used to collect the samples. The collected samples were placed in a thermocol box. The temperature in the box was maintained at $4^{\circ} \mathrm{C}$ by using ice packs. The microbial isolation was done by streak plate method on nutrient agar and on selective media for their identification (Sherman Cappuccino 2009). The final identification of resulted isolates was done by the biochemical tests in accordance to the Bergey's Manual.

The data were subjected to a software program PAST (Hammer et al., 2001) which generates diversity indices. The formula designed for various indices are described below.

These indices were used to obtain estimation of species diversity, species richness and species evenness.

1. Shannon and Weaver (1949) and Simpson (1949) diversity index value were obtained by using the following equation:

(Shannon's index)

$$
-\sum_{i}\left(\frac{n_{i}}{N} \cdot \log _{2}\left(\frac{n_{i}}{N}\right)\right)
$$

(Simpson index)

$$
\frac{\sum_{i} n_{i}\left(n_{i}-1\right)}{N(N-1)}
$$

2. Species richness $\left(R_{1}\right.$ and $\left.R_{2}\right)$ obtained using following equation

$\mathrm{R}_{1}=($ Margalef, 1958)

$\mathrm{R}_{2}=($ Menhinick, 1964)

Where,

$$
\begin{aligned}
& \frac{S-1}{\ln N} \\
& \frac{S}{\sqrt{\sum_{i} n_{i}}}
\end{aligned}
$$

$\mathrm{R}=$ Index of species richness

$\mathrm{S}=$ Total number of species
$\mathrm{N}=$ Total number of individuals

3. Species evenness was determined by using the following expression.

Shannon's equitability $\left(\mathrm{E}_{\mathrm{H}}\right)$ can be calculated by following equation.

$$
-\frac{\sum_{i}\left(\frac{n_{i}}{N} \cdot \ln \left(\frac{n_{i}}{N}\right)\right)}{\ln N}
$$

Equitability assumes a value between 0 and 1 being complete evenness.

4. Dominance index is used to characterize most conspicuous and abundant species with its relative importance related to degree of influence it has on ecosystem components.

Dominance index $=1-\left(\frac{\sum_{i} n_{i}\left(n_{i}-1\right)}{N(N-1)}\right)$

5. The Berger - Parker Dominance Index is a simple measure of the numerical importance of the most abundance species.

Berger - Parker Dominance Index $=\frac{\frac{n_{\max }}{N}}{N}$

\section{Results and Discussion}

\section{Stream water}

1. Simpson Index: The Simpson index of the stream in the both years was in the range of 0.1163 - 0.2971. In summer season it was in the range of 0.1202 0.2881 (table 1 ). In rainy season it was in the range of $0.1184-0.2971$ (table 5). In winter season it was in the range of $0.1163-0.2134$ (table 9). The water sample showed the maximum in Valasi (0.2971) during rainy season and minimum in Tokkuru (0.1163) during winter season. 
2. Shannon Index: The Shannon index of the stream in the both years was in the range of 2.043 - 2.966. In summer season it was in the range of $2.01-2.939$ (table 1). In '] rainy season it was in the range of 2.043 - 2.966 (table 5). In winter season it was in the range of $2.437-2.958$ (table 9). The water sample showed the maximum in Kothuru (2.966) during rainy season and minimum in Valasi (2.043) during rainy season.

3. Menhinick Index: The Menhinick index of the stream in the both years was in the range of $0.1526-1.414$. In summer season it was in the range of $0.1526-$ 1.414 (table 1). In rainy season it was in the range of $0.1603-1.131$ (table 5). In winter season it was in the range of 0.1617 - 1.249 (table 9). The water sample showed the maximum in Tokkuru (1.414) during summer season and minimum in Valasi(0.1526) during summer season.

4. Margalef Richness Index: The Margalef richness index of the stream in the both years was in the range of $0.8474-1.953$. In summer season it was in the range of $0.884-1.953$ (table 1 ). In rainy season it was in the range of $0.8987-1.953$ (table $5)$. In winter season it was in the range of $0.8474-1.885$ (table 9). The water sample showed the maximum in Borra (1.953) during both summer season and rainy seasons and minimum in Valasi (0.8474) during winter season.

5. Equitability Index: The Equitability index of the stream in the both years was in the range of $0.6701-1.755$. In summer season it was in the range of $0.6701-1.755$ (table 1). In rainy season it was in the range of $0.681-1.602$ (table $5)$. In winter season it was in the range of $0.8124-0.986$ (table 9). The water sample showed the maximum in Garugubilli (1.755) during both summer season and minimum in Valasi (0.6701) during summer season.

6. Berger-Parker Dominance Index: The Berger-Parker Dominance index of the stream in the both years was in the range of $0.1662-0.4248$. In summer season it was in the range of $0.1852-0.3935$ (table 1). In rainy season it was in the range of $0.1667-0.4248$ (table 5). In winter season it was in the range of $0.1662-0.337$ (table 9). The water sample showed the maximum in Valasi $(0.4248)$ during rainy season and minimum in Pedabidda (0.1667) during rainy season.

7. Dominance Index: The Dominance index of the stream in the both years was in the range of $0.7029-0.8837$. In summer season it was in the range of $0.7029-0.8798$ (table 1 ). In rainy season it was in the range of $0.7029-0.8783$ (table 5). In winter season it was in the range of $0.7866-0.8837$ (table 9). The water sample showed the maximum in Tokkuru (0.8837) during winter season and minimum in Valasi (0.7029) during rainy season.

\section{Tap water (Protected stream)}

1. Simpson Index: The Simpson index of the tap in the both years was in the range of $0.1163-0.1399$. In summer season it was in the range of $0.1257-0.1399$ (table 2). In rainy season it was in the range of $0.1221-0.1272$ (table 6). In winter season it was in the range of $0.1163-0.1257$ (table 10). The water sample showed the maximum in Gumma kota (0.1399) during summer season and minimum in Borra (0.1163) during winter season. 
2. Shannon Index: The Shannon index of the tap in the both years was in the range of $2.876-2.982$. In summer season it was in the range of $2.876-2.941$ (table 2). In rainy season it was in the range of $2.943-2.975$ (table 6). In winter season it was in the range of $2.946-2.982$ (table 10). The water sample showed the maximum in Borra (2.982) during winter season and minimum in Gumma kota (2.876) during summer season.

3. Menhinick Index: The Menhinick index of the tap in the both years was in the range of $0.6737-0.93$. In summer season it was in the range of $0.7883-0.8677$ (table 2). In rainy season it was in the range of $0.6737-0.7303$ (table 6). In winter season it was in the range of $0.8-$ 0.93 (table 10). The water sample showed the maximum in Borra (0.93) during winter season and minimum in Gumma kota (0.6737) during rainy season.

4. Margalef Richness Index: The Margalef richness index of the tap in the both years was in the range of $1.414-1.626$. In summer season it was in the range of 1.51 -1.579 (table 2). In rainy season it was in the range of $1.414-1.579$ (table 6). In winter season it was in the range of 1.52 - 1.626 (table 10). The water sample showed the maximum in Borra (1.626) during winter season and minimum in Gumma kota (1.414) during rainy season.

5. Equitability Index: The Equitability index of the tap in the both years was in the range of $0.9587-0.9939$. In summer season it was in the range of 0.9587 0.9804 (table 2). In rainy season it was in the range of $0.9809-0.9916$ (table 6). In winter season it was in the range of 0.982 - 0.9939 (table 10). The water sample showed the maximum in Borra (0.9939) during winter season and minimum in
Gumma kota (0.9587) during summer season.

6. Berger-Parker Dominance Index: The Berger-Parker Dominance index of the tap in the both years was in the range of $0.1622-0.2475$. In summer season it was in the range of $0.1957-0.2475$ (table 2). In rainy season it was in the range of $0.1639-0.194$ (table 6). In winter season it was in the range of $0.1622-0.1928$ (table 10). The water sample showed the maximum in Borra $(0.1622)$ during winter season and minimum in Gumma kota (0.2475) during summer season.

7. Dominance Index: The Dominance index of the tap in the both years was in the range of $0.8601-0.8837$. In summer season it was in the range of $0.8601-$ 0.8743 (table 2). In rainy season it was in the range of $0.8728-0.8779$ (table 6). In winter season it was in the range of $0.8743-0.8837$ (table 10). The water sample showed the maximum in Borra (0.8837) during winter season and minimum in Gumma kota (0.8601) during summer season.

\section{Bore water}

1. Simpson Index: The Simpson index of the bore in the both years was in the range of $0.1193-0.4046$. In summer season it was in the range of 0.1435 0.306 (table 3). In rainy season it was in the range of $0.1202-0.4046$ (table 7). In winter season it was in the range of $0.1193-0.3216$ (table 11). The water sample showed the maximum in Valasi (0.4046) during rainy season and minimum in Tokkuru (0.1193) during winter season. 
2. Shannon Index: The Shannon index of the bore in the both years was in the range of $1.662-2.96$. In summer season it was in the range of $2.115-2.958$ (table $3)$. In rainy season it was in the range of $1.662-2.954$ (table 7). In winter season it was in the range of $1.842-2.96$ (table 11). The water sample showed the maximum in Garugubilli (2.96) during winter season and minimum in Valasi (1.662) during rainy season.

3. Menhinick Index: The Menhinick index of the bore in the both years was in the range of $0.1333-1.352$. In summer season it was in the range of 0.1333 1.352 (table 3 ). In rainy season it was in the range of $0.2194-1$ (table 7 ). In winter season it was in the range of 0.171 - 1.167 (table 11). The water sample showed the maximum in Tokkuru (1.352) during summer season and minimum in Valasi (0.1333) during summer season.

4. Margalef Richness Index: The Margalef richness index of the bore in the both years was in the range of $0.8548-1.969$. In summer season it was in the range of $0.8548-1.969$ (table 3 ). In rainy season it was in the range of $0.9732-1.683$ (table 7). In winter season it was in the range of $0.9102-1.818$ (table 11). The water sample showed the maximum in Tokkuru (1.969) during summer season and minimum in Valasi (0.8548) during summer season.

5. Equitability Index: The Equitability index of the bore in the both years was in the range of $0.554-0.9866$. In summer season it was in the range of 0.7051 0.9859 (table 3 ). In rainy season it was in the range of $0.554-0.9848$ (table 7 ). In winter season it was in the range of $0.6141-0.9866$ (table 11). The water sample showed the maximum in
Garugubilli (0.9866) during winter season and minimum in Valasi (0.554) during rainy season.

6. Berger-Parker Dominance Index: The Berger-Parker Dominance index of the bore in the both years was in the range of $0.1562-0.5451$. In summer season it was in the range of $0.1695-0.4688$ (table 3 ). In rainy season it was in the range of $0.1562-0.5451$ (table 7 ). In winter season it was in the range of $0.1786-0.4228$ (table 11). The water sample showed the maximum in Tokkuru (1.562) during rainy season and minimum in Valasi (0.4228) during rainy season.

7. Dominance Index: The Dominance index of the bore in the both years was in the range of $0.5954-0.8825$. In summer season it was in the range of 0.694 0.8825 (table 3 ). In rainy season it was in the range of $0.5954-0.8798$ (table 7 ). In winter season it was in the range of $0.6784-0.8798$ (table 11). The water sample showed the maximum in Garugubilli (0.8825) during summer season and minimum in Valasi (0.5954) during rainy season.

\section{Well water}

1. Simpson Index: The Simpson index of the well in the both years was in the range of $0.1162-0.6104$. In summer season it was in the range of 0.1246 0.6104 (table 4 ). In rainy season it was in the range of $0.1198-0.4097$ (table 8). In winter season it was in the range of $0.1162-0.3813$ (table 12). The water sample showed the maximum in Valasi (0.6104) during summer season and minimum in Borra (0.1162) during winter season. 
2. Shannon Index: The Shannon index of the well in the both years was in the range of $1.742-2.988$. In summer season it was in the range of $1.961-2.941$ (table 4). In rainy season it was in the range of $1.742-2.977$ (table 8). In winter season it was in the range of $1.745-2.988$ (table 12). The water sample showed the maximum in Kondiba (2.988) during winter season and minimum in Valasi (1.961) during summer season.

3. Menhinick Index: The Menhinick index of the well in the both years was in the range of $0.1306-1.298$. In summer season it was in the range of 0.1737 1.298 (table 4). In rainy season it was in the range of $0.1306-0.9923$ (table 8). In winter season it was in the range of $0.1319-1.167$ (table 12). The water sample showed the maximum in Pedabidda (1.298) during summer season and minimum in Valasi (0.1306) during rainy season.

4. Margalef Richness Index: The Margalef richness index of the well in the both years was in the range of $0.8506-1.924$. In summer season it was in the range of $0.9139-1.924$ (table 4). In rainy season it was in the range of $0.8506-1.677$ (table 8). In winter season it was in the range of $0.8525-1.818$ (table 12). The water sample showed the maximum in Pedabidda (1.924) during summer season and minimum in Valasi (0.8506) during rainy season.

5. Equitability Index: The Equitability index of the well in the both years was in the range of $0.4105-1.548$. In summer season it was in the range of 0.4105 1.548 (table 4). In rainy season it was in the range of $0.5805-0.9924$ (table 8 ). In winter season it was in the range of $0.5818-0.9961$ (table 12). The water sample showed the maximum in Bheempolu (1.548) during summer season and minimum in Valasi (0.4105) during summer season.

6. Berger-Parker Dominance Index: The Berger-Parker Dominance index of the well in the both years was in the range of $0.1579-0.7702$. In summer season it was in the range of $0.1918-0.7702$ (table 4). In rainy season it was in the range of $0.1667-0.58$ (table 8 ). In winter season it was in the range of 0.1579 0.5146 (table 12). The water sample showed the maximum in Valasi (0.7702) during summer season and minimum in Kondiba (0.1579) during winter season.

7. Dominance Index: The Dominance index of the well in the both years was in the range of $0.6187-0.8846$. In summer season it was in the range of 0.6698 0.8656 (table 4 ). In rainy season it was in the range of $0.6698-0.8752$ (table 8 ). In winter season it was in the range of $0.6187-0.8846$ (table 12). The water sample showed the maximum in Kondiba (0.8846) during winter season and minimum in Valasi (0.6187) during winter season.

In the present investigation, based on Simpson index value $(>0)$, the drinking water samples under study were reported as non-polluted, While calculating the Shannon-Wiener index, a value of this index above 3 indicates clean water, whereas values lower than this would indicate pollution. William(1975) implied that a high value if diversity index $\left(\mathrm{H}^{\prime}\right)$ suggests a more healthy ecosystem, while a low value suggests a less healthy or degraded ecosystem. Shannon-Wiener index value of all the panchyaths except bore and well water samples of Valasi panchayath were nearer to 3 , indicative of oligotrophy. 
Table.1 Biodiversity Indices of Pathogenic bacteria in Steam water (unprotected) in summer season

\begin{tabular}{|c|c|c|c|c|c|c|c|c|c|c|c|c|c|c|c|}
\hline \multirow{3}{*}{$\begin{array}{l}\text { S. } \\
\text { No }\end{array}$} & \multirow{3}{*}{$\begin{array}{l}\text { Name of } \\
\text { Panchayath }\end{array}$} & \multicolumn{14}{|c|}{ Index } \\
\hline & & \multicolumn{2}{|c|}{ Simpson Index } & \multicolumn{2}{|c|}{$\begin{array}{l}\text { Dominance } \\
\text { Index }\end{array}$} & \multicolumn{2}{|c|}{$\begin{array}{l}\text { Shannon } \\
\text { Index }\end{array}$} & \multicolumn{2}{|c|}{$\begin{array}{l}\text { Menhinick } \\
\text { Index }\end{array}$} & \multicolumn{2}{|c|}{$\begin{array}{c}\text { Berger-Parker } \\
\text { Dominance Index }\end{array}$} & \multicolumn{2}{|c|}{$\begin{array}{l}\text { Equitability } \\
\text { Index }\end{array}$} & \multicolumn{2}{|c|}{$\begin{array}{c}\text { Margalef } \\
\text { Richness Index }\end{array}$} \\
\hline & & 1 & 2 & 1 & 2 & 1 & 2 & 1 & 2 & 1 & 2 & 1 & 2 & 1 & 2 \\
\hline 1 & Borra & 0.127 & 0.1394 & 0.873 & 0.8606 & 2.86 & 2.808 & 1.333 & 1.298 & 0.25 & 0.2632 & 0.9533 & 0.9359 & 1.953 & 1.924 \\
\hline 2 & Tokkuru & 0.125 & 0.127 & 0.875 & 0.873 & 2.858 & 2.86 & 1.414 & 1.333 & 0.25 & 0.25 & 0.9528 & 0.9533 & 2.02 & 1.953 \\
\hline 3 & Valasi & 0.2881 & 0.2216 & 0.7119 & 0.7784 & 2.01 & 2.352 & 0.2434 & 0.1526 & 0.3935 & 0.3002 & 0.6701 & 0.7841 & 1.002 & 0.884 \\
\hline 4 & Gumma & 0.1337 & 0.1394 & 0.8663 & 0.8606 & 2.833 & 2.808 & 1.298 & 1.298 & 0.2632 & 0.2632 & 0.9445 & 0.9359 & 1.924 & 1.924 \\
\hline 5 & Pedabidda & 0.1394 & 0.1404 & 0.8606 & 0.8596 & 2.808 & 2.827 & 1.298 & 1.193 & 0.2632 & 0.2667 & 0.9359 & 0.9424 & 1.924 & 1.839 \\
\hline 6 & Kondiba & 0.1404 & 0.1344 & 0.8596 & 0.8656 & 2.827 & 2.845 & 1.193 & 1.143 & 0.2667 & 0.2041 & 0.9424 & 0.9485 & 1.839 & 1.799 \\
\hline 7 & Garugubilli & 0.1314 & 0.1202 & 0.8686 & 0.8798 & 2.877 & 2.929 & 1.167 & 1.089 & 0.2553 & 0.1852 & 0.959 & 1.755 & 1.818 & 0.9763 \\
\hline 8 & Gumma kota & 0.1202 & 0.1285 & 0.8798 & 0.8715 & 2.929 & 2.905 & 1.089 & 1.008 & 0.1852 & 0.2222 & 0.9763 & 0.9682 & 1.755 & 1.69 \\
\hline 9 & Bheempolu & 0.1259 & 0.1345 & 0.8741 & 0.8655 & 2.931 & 2.893 & 0.8889 & 0.8577 & 0.1975 & 0.2299 & 0.9771 & 0.9645 & 1.593 & 1.567 \\
\hline 10 & Kothuru & 0.1339 & 0.1261 & 0.8661 & 0.8739 & 2.897 & 2.939 & 0.8677 & 0.8251 & 0.2353 & 0.1915 & 0.9658 & 0.9797 & 1.576 & 1.541 \\
\hline
\end{tabular}

Table.2 Biodiversity Indices of Pathogenic bacteria in tap water (protected stream) in summer season

\begin{tabular}{|c|c|c|c|c|c|c|c|c|c|c|c|c|c|c|c|}
\hline \multirow{3}{*}{$\begin{array}{l}\text { S. } \\
\text { No }\end{array}$} & \multirow{3}{*}{$\begin{array}{c}\text { Name of } \\
\text { Panchayath }\end{array}$} & \multicolumn{14}{|c|}{ Index } \\
\hline & & \multicolumn{2}{|c|}{ Simpson Index } & \multicolumn{2}{|c|}{$\begin{array}{l}\text { Dominance } \\
\text { Index }\end{array}$} & \multicolumn{2}{|c|}{$\begin{array}{l}\text { Shannon } \\
\text { Index }\end{array}$} & \multicolumn{2}{|c|}{$\begin{array}{l}\text { Menhinick } \\
\text { Index }\end{array}$} & \multicolumn{2}{|c|}{$\begin{array}{c}\text { Berger-Parker } \\
\text { Dominance Index }\end{array}$} & \multicolumn{2}{|c|}{$\begin{array}{l}\text { Equitability } \\
\text { Index }\end{array}$} & \multicolumn{2}{|c|}{$\begin{array}{c}\text { Margalef } \\
\text { Richness Index }\end{array}$} \\
\hline & & 1 & 2 & 1 & 2 & 1 & 2 & 1 & 2 & 1 & 2 & 1 & 2 & 1 & 2 \\
\hline 1 & Borra & 0.1339 & 0.1257 & 0.8661 & 0.8743 & 2.897 & 2.941 & 0.8677 & 0.8341 & 0.2353 & 0.1957 & 0.9658 & 0.9804 & 1.576 & 1.548 \\
\hline 2 & Tokkuru & 0.1297 & 0.1289 & 0.8703 & 0.8711 & 2.922 & 2.926 & 0.8251 & 0.8165 & 0.2128 & 0.2083 & 0.9741 & 0.9754 & 1.541 & 1.534 \\
\hline 3 & Valasi & - & - & - & - & - & - & - & - & - & - & - & - & - & - \\
\hline 4 & Gumma & - & - & - & - & - & - & - & - & - & - & - & - & - & - \\
\hline 5 & Pedabidda & - & - & - & - & - & - & - & - & - & - & - & - & - & - \\
\hline 6 & Kondiba & - & - & - & - & - & - & - & - & - & - & - & - & - & - \\
\hline 7 & Garugubilli & - & - & - & - & - & - & - & - & - & - & - & - & - & - \\
\hline 8 & Gumma kota & 0.1398 & 0.1399 & 0.8602 & 0.8601 & 2.878 & 2.876 & 0.796 & 0.7883 & 0.2475 & 0.2427 & 0.9594 & 0.9587 & 1.517 & 1.51 \\
\hline 9 & Bheempolu & - & - & - & - & - & - & - & - & - & - & - & - & - & - \\
\hline 10 & Kothuru & - & - & - & - & - & - & - & - & - & - & - & - & - & - \\
\hline
\end{tabular}


Table.3 Biodiversity Indices of Pathogenic bacteria in Bore water in summer season

\begin{tabular}{|c|c|c|c|c|c|c|c|c|c|c|c|c|c|c|c|}
\hline \multirow{3}{*}{$\begin{array}{l}\text { S. } \\
\text { No }\end{array}$} & \multirow{3}{*}{$\begin{array}{l}\text { Name of } \\
\text { Panchayath }\end{array}$} & \multicolumn{14}{|c|}{ Index } \\
\hline & & \multicolumn{2}{|c|}{ Simpson Index } & \multicolumn{2}{|c|}{$\begin{array}{l}\text { Dominance } \\
\text { Index }\end{array}$} & \multicolumn{2}{|c|}{$\begin{array}{l}\text { Shannon } \\
\text { Index }\end{array}$} & \multicolumn{2}{|c|}{$\begin{array}{l}\text { Menhinick } \\
\text { Index }\end{array}$} & \multicolumn{2}{|c|}{$\begin{array}{c}\text { Berger-Parker } \\
\text { Dominance Index }\end{array}$} & \multicolumn{2}{|c|}{$\begin{array}{l}\text { Equitability } \\
\text { Index }\end{array}$} & \multicolumn{2}{|c|}{$\begin{array}{c}\text { Margalef } \\
\text { Richness Index }\end{array}$} \\
\hline & & 1 & 2 & 1 & 2 & 1 & 2 & 1 & 2 & 1 & 2 & 1 & 2 & 1 & 2 \\
\hline 1 & Borra & - & - & - & - & - & - & - & - & - & - & - & - & - & - \\
\hline 2 & Tokkuru & 0.1311 & 0.1404 & 0.8689 & 0.8596 & 2.836 & 2.827 & 1.352 & 1.193 & 0.2286 & 0.2667 & 0.9453 & 0.9424 & 1.969 & 1.839 \\
\hline 3 & Valasi & 0.306 & 0.1842 & 0.694 & 0.8158 & 2.115 & 2.565 & 0.1907 & 0.1333 & 0.4688 & 0.2569 & 0.7051 & 0.8551 & 0.9367 & 0.8548 \\
\hline 4 & Gumma & 0.1426 & 0.1246 & 0.8574 & 0.8754 & 2.791 & 2.902 & 1.315 & 1.18 & 0.2703 & 0.2174 & 0.9303 & 0.9674 & 1.939 & 1.828 \\
\hline 5 & Pedabidda & 0.1363 & 0.1344 & 0.8637 & 0.8656 & 2.825 & 2.845 & 1.281 & 1.143 & 0.2564 & 0.2041 & 0.9415 & 0.9485 & 1.911 & 1.799 \\
\hline 6 & Kondiba & 0.1246 & 0.1202 & 0.8754 & 0.8798 & 2.902 & 2.929 & 1.18 & 1.089 & 0.2174 & 0.1852 & 0.9674 & 0.9763 & 1.828 & 1.755 \\
\hline 7 & Garugubilli & 0.1372 & 0.1175 & 0.8628 & 0.8825 & 2.829 & 2.958 & 1.18 & 1.042 & 0.2174 & 0.1695 & 0.943 & 0.9859 & 1.828 & 1.717 \\
\hline 8 & Gumma kota & 0.133 & 0.1246 & 0.867 & 0.8754 & 2.852 & 2.902 & 1.155 & 1.18 & 0.2083 & 0.2174 & 0.9508 & 0.9674 & 1.808 & 1.828 \\
\hline 9 & Bheempolu & 0.1273 & 0.1386 & 0.8727 & 0.8614 & 2.884 & 2.823 & 1.193 & 1.143 & 0.2222 & 0.2041 & 0.9615 & 0.9411 & 1.839 & 1.799 \\
\hline 10 & Kothuru & 0.1404 & 0.1435 & 0.8596 & 0.8565 & 2.827 & 2.806 & 1.193 & 1.12 & 0.2667 & 0.2353 & 0.9424 & 0.9352 & 1.839 & 1.78 \\
\hline
\end{tabular}

Table.4 Biodiversity Indices of Pathogenic bacteria in Well water in summer season

\begin{tabular}{|c|c|c|c|c|c|c|c|c|c|c|c|c|c|c|c|}
\hline \multirow{3}{*}{$\begin{array}{l}\text { S. } \\
\text { No }\end{array}$} & \multirow{3}{*}{$\begin{array}{c}\text { Name of } \\
\text { Panchayath }\end{array}$} & \multicolumn{14}{|c|}{ Index } \\
\hline & & \multicolumn{2}{|c|}{ Simpson Index } & \multicolumn{2}{|c|}{$\begin{array}{l}\text { Dominance } \\
\text { Index }\end{array}$} & \multicolumn{2}{|c|}{$\begin{array}{l}\text { Shannon } \\
\text { Index }\end{array}$} & \multicolumn{2}{|c|}{$\begin{array}{l}\text { Menhinick } \\
\text { Index }\end{array}$} & \multicolumn{2}{|c|}{$\begin{array}{c}\text { Berger-Parker } \\
\text { Dominance Index }\end{array}$} & \multicolumn{2}{|c|}{$\begin{array}{l}\text { Equitability } \\
\text { Index }\end{array}$} & \multicolumn{2}{|c|}{$\begin{array}{c}\text { Margalef } \\
\text { Richness Index }\end{array}$} \\
\hline & & 1 & 2 & 1 & 2 & 1 & 2 & 1 & 2 & 1 & 2 & 1 & 2 & 1 & 2 \\
\hline 1 & Borra & 0.1246 & 0.1344 & 0.8754 & 0.8656 & 2.902 & 2.845 & 1.18 & 1.143 & 0.2174 & 0.2041 & 0.9674 & 0.9485 & 1.828 & 1.799 \\
\hline 2 & Tokkuru & - & - & - & - & - & - & - & - & - & - & - & - & - & - \\
\hline 3 & Valasi & 0.3302 & 0.6104 & 0.6698 & 0.3896 & 1.961 & 1.232 & 0.1737 & 0.2308 & 0.4125 & 0.7702 & 0.6537 & 0.4105 & 0.9139 & 0.9872 \\
\hline 4 & Gumma & - & - & - & - & - & - & - & - & - & - & - & - & - & - \\
\hline 5 & Pedabidda & 0.1394 & 0.1337 & 0.8606 & 0.8663 & 2.808 & 2.833 & 1.298 & 1.298 & 0.2632 & 0.2632 & 0.9359 & 0.9445 & 1.924 & 1.924 \\
\hline 6 & Kondiba & 0.1248 & 0.1339 & 0.8752 & 0.8661 & 2.931 & 2.897 & 0.9363 & 0.8677 & 0.1918 & 0.2353 & 0.9771 & 0.9658 & 1.632 & 1.576 \\
\hline 7 & Garugubilli & - & - & - & - & - & - & - & - & - & - & - & - & - & - \\
\hline 8 & Gumma kota & 0.1269 & 0.1272 & 0.8731 & 0.8728 & 2.926 & 2.929 & 0.9001 & 0.8386 & 0.2025 & 0.1978 & 0.9752 & 0.9763 & 1.602 & 1.552 \\
\hline 9 & Bheempolu & 0.1259 & 0.1257 & 0.8741 & 0.8743 & 2.931 & 2.941 & 0.8889 & 0.8341 & 0.1975 & 0.1957 & 0.9771 & 1.548 & 1.593 & 0.9804 \\
\hline 10 & Kothuru & - & - & - & - & - & - & - & - & - & - & - & - & - & - \\
\hline
\end{tabular}


Table.5 Biodiversity Indices of Pathogenic bacteria in Steam water (unprotected) in rainy season

\begin{tabular}{|c|c|c|c|c|c|c|c|c|c|c|c|c|c|c|c|}
\hline \multirow{3}{*}{$\begin{array}{l}\text { S. } \\
\text { No }\end{array}$} & \multirow{3}{*}{$\begin{array}{l}\text { Name of } \\
\text { Panchayath }\end{array}$} & \multicolumn{14}{|c|}{ Index } \\
\hline & & \multicolumn{2}{|c|}{ Simpson Index } & \multicolumn{2}{|c|}{$\begin{array}{l}\text { Dominance } \\
\text { Index }\end{array}$} & \multicolumn{2}{|c|}{$\begin{array}{l}\text { Shannon } \\
\text { Index }\end{array}$} & \multicolumn{2}{|c|}{$\begin{array}{l}\text { Menhinick } \\
\text { Index }\end{array}$} & \multicolumn{2}{|c|}{$\begin{array}{c}\text { Berger-Parker } \\
\text { Dominance Index }\end{array}$} & \multicolumn{2}{|c|}{$\begin{array}{l}\text { Equitability } \\
\text { Index }\end{array}$} & \multicolumn{2}{|c|}{$\begin{array}{c}\text { Margalef } \\
\text { Richness Index }\end{array}$} \\
\hline & & 1 & 2 & 1 & 2 & 1 & 2 & 1 & 2 & 1 & 2 & 1 & 2 & 1 & 2 \\
\hline 1 & Borra & 0.1224 & 0.1251 & 0.8776 & 0.8749 & 2.912 & 2.907 & 1.131 & 1.042 & 0.2 & 0.1695 & 0.9706 & 0.969 & 1.789 & 1.717 \\
\hline 2 & Tokkuru & 0.123 & 0.1251 & 0.877 & 0.8749 & 2.915 & 2.907 & 1.089 & 1.042 & 0.1852 & 0.1695 & 0.9718 & 0.969 & 1.755 & 1.717 \\
\hline 3 & Valasi & 0.2971 & 0.2517 & 0.7029 & 0.7483 & 2.043 & 2.266 & 0.1629 & 0.1603 & 0.4248 & 0.3112 & 0.681 & 0.7555 & 0.8987 & 0.8951 \\
\hline 4 & Gumma & 0.1258 & 0.129 & 0.8742 & 0.871 & 2.897 & 2.889 & 1.089 & 1.016 & 0.1852 & 0.1935 & 0.9657 & 0.9629 & 1.755 & 1.696 \\
\hline 5 & Pedabidda & 0.1184 & 0.1217 & 0.8816 & 0.8783 & 2.964 & 2.943 & 0.9562 & 0.9428 & 0.1714 & 0.1667 & 0.9882 & 0.9811 & 1.648 & 1.637 \\
\hline 6 & Kondiba & .1253 & 0.1251 & 0.8747 & 0.8749 & 2.927 & 2.928 & 0.9177 & 0.9117 & 0.1842 & 0.1818 & 0.9756 & 0.976 & 1.616 & 1.611 \\
\hline 7 & Garugubilli & 0.1269 & 0.1373 & 0.8731 & 0.8627 & 2.926 & 2.87 & 0.9001 & 0.9001 & 0.2025 & 0.2278 & 0.9752 & 1.602 & 1.602 & 0.9568 \\
\hline 8 & Gumma kota & 0.1224 & 0.1239 & 0.8776 & 0.8761 & 2.962 & 2.96 & 0.8251 & 0.7883 & 0.1702 & 0.1942 & 0.9874 & 0.9866 & 1.541 & 1.51 \\
\hline 9 & Bheempolu & 0.1244 & 0.1248 & 0.8756 & 0.8752 & 2.964 & 2.958 & 0.7155 & 0.7127 & 0.184 & 0.1746 & 0.988 & 0.9859 & 1.45 & 1.447 \\
\hline 10 & Kothuru & 0.1241 & 0.1279 & 0.8759 & 0.8721 & 2.966 & 2.943 & 0.7099 & 0.7044 & 0.1811 & 0.1938 & 0.9885 & 0.981 & 1.445 & 1.44 \\
\hline
\end{tabular}

Table.6 Biodiversity Indices of Pathogenic bacteria in tap water (protected stream) in rainy season

\begin{tabular}{|c|c|c|c|c|c|c|c|c|c|c|c|c|c|c|c|}
\hline \multirow{3}{*}{$\begin{array}{l}\text { S. } \\
\text { No }\end{array}$} & \multirow{3}{*}{$\begin{array}{c}\text { Name of } \\
\text { Panchayath }\end{array}$} & \multicolumn{14}{|c|}{ Index } \\
\hline & & \multicolumn{2}{|c|}{ Simpson Index } & \multicolumn{2}{|c|}{$\begin{array}{l}\text { Dominance } \\
\text { Index }\end{array}$} & \multicolumn{2}{|c|}{$\begin{array}{l}\text { Shannon } \\
\text { Index }\end{array}$} & \multicolumn{2}{|c|}{$\begin{array}{l}\text { Menhinick } \\
\text { Index }\end{array}$} & \multicolumn{2}{|c|}{$\begin{array}{c}\text { Berger-Parker } \\
\text { Dominance Index }\end{array}$} & \multicolumn{2}{|c|}{$\begin{array}{l}\text { Equitability } \\
\text { Index }\end{array}$} & \multicolumn{2}{|c|}{$\begin{array}{c}\text { Margalef } \\
\text { Richness Index }\end{array}$} \\
\hline & & 1 & 2 & 1 & 2 & 1 & 2 & 1 & 2 & 1 & 2 & 1 & 2 & 1 & 2 \\
\hline 1 & Borra & 0.1221 & 0.1272 & 0.8779 & 0.8728 & 2.975 & 2.943 & 0.7243 & 0.7303 & 0.1639 & 0.1833 & 0.9916 & 0.9809 & 1.457 & 1.462 \\
\hline 2 & Tokkuru & 0.1272 & 0.1265 & 0.8728 & 0.8735 & 2.943 & 2.955 & 0.7303 & 0.6911 & 0.1833 & 0.194 & 0.9809 & 0.9851 & 1.462 & 1.429 \\
\hline 3 & Valasi & - & - & - & - & - & - & - & - & - & - & - & - & - & - \\
\hline 4 & Gumma & - & - & - & - & - & - & - & - & - & - & - & - & - & - \\
\hline 5 & Pedabidda & - & - & - & - & - & - & - & - & - & - & - & - & - & - \\
\hline 6 & Kondiba & - & - & - & - & - & - & - & - & - & - & - & - & - & - \\
\hline 7 & Garugubilli & - & - & - & - & - & - & - & - & - & - & - & - & - & - \\
\hline 8 & Gumma kota & 0.1252 & 0.125 & 0.8748 & 0.875 & 2.962 & 2.963 & 0.6786 & 0.6737 & 0.1799 & 0.1773 & 0.9872 & 0.9876 & 1.419 & 1.414 \\
\hline 9 & Bheempolu & - & - & - & - & - & - & - & - & - & - & - & - & - & - \\
\hline 10 & Kothuru & - & - & - & - & - & - & - & - & - & - & - & - & - & - \\
\hline
\end{tabular}


Table.7 Biodiversity Indices of Pathogenic bacteria in Bore water in rainy season

\begin{tabular}{|c|c|c|c|c|c|c|c|c|c|c|c|c|c|c|c|}
\hline \multirow{3}{*}{$\begin{array}{l}\text { S. } \\
\text { No }\end{array}$} & \multirow{3}{*}{$\begin{array}{l}\text { Name of } \\
\text { Panchayath }\end{array}$} & \multicolumn{14}{|c|}{ Index } \\
\hline & & \multicolumn{2}{|c|}{ Simpson Index } & \multicolumn{2}{|c|}{$\begin{array}{l}\text { Dominance } \\
\text { Index }\end{array}$} & \multicolumn{2}{|c|}{$\begin{array}{l}\text { Shannon } \\
\text { Index }\end{array}$} & \multicolumn{2}{|c|}{$\begin{array}{l}\text { Menhinick } \\
\text { Index }\end{array}$} & \multicolumn{2}{|c|}{$\begin{array}{c}\text { Berger-Parker } \\
\text { Dominance Index }\end{array}$} & \multicolumn{2}{|c|}{$\begin{array}{l}\text { Equitability } \\
\text { Index }\end{array}$} & \multicolumn{2}{|c|}{$\begin{array}{c}\text { Margalef } \\
\text { Richness Index } \\
\end{array}$} \\
\hline & & 1 & 2 & 1 & 2 & 1 & 2 & 1 & 2 & 1 & 2 & 1 & 2 & 1 & 2 \\
\hline 1 & Borra & - & - & - & - & - & - & - & - & - & - & - & - & - & - \\
\hline 2 & Tokkuru & 0.121 & 0.1226 & 0.879 & 0.8774 & 2.934 & 2.929 & 1 & 0.9774 & 0.1562 & 0.1791 & 0.9779 & 0.9762 & 1.683 & 1.665 \\
\hline 3 & Valasi & 0.4046 & 0.2483 & 0.5954 & 0.7517 & 1.662 & 2.271 & 0.2194 & 0.4634 & 0.5451 & 0.3188 & 0.554 & 0.7571 & 0.9732 & 1.229 \\
\hline 4 & Gumma & 0.1236 & 0.1198 & 0.8764 & 0.8802 & 2.922 & 2.954 & 0.9923 & 0.9631 & 0.1846 & 0.1739 & 0.974 & 0.9848 & 1.677 & 1.653 \\
\hline 5 & Pedabidda & 0.1202 & 0.1202 & 0.8798 & 0.8798 & 2.949 & 2.949 & 0.9631 & 0.9631 & 0.1739 & 0.1739 & 0.9831 & 0.9831 & 1.653 & 1.653 \\
\hline 6 & Kondiba & 0.1202 & 0.1242 & 0.8798 & 0.8758 & 2.949 & 2.932 & 0.9631 & 0.9177 & 0.1739 & 0.1842 & 0.9831 & 0.9775 & 1.653 & 1.616 \\
\hline 7 & Garugubilli & 0.1236 & 0.1235 & 0.8764 & 0.8765 & 2.934 & 2.937 & 0.9428 & 0.9058 & 0.1944 & 0.1795 & 0.9781 & 0.9789 & 1.637 & 1.607 \\
\hline 8 & Gumma kota & 0.1236 & 0.1221 & 0.8764 & 0.8779 & 2.922 & 2.941 & 0.9923 & 0.9428 & 0.1846 & 0.1667 & 0.974 & 0.9804 & 1.677 & 1.637 \\
\hline 9 & Bheempolu & 0.1202 & 0.1218 & 0.8798 & 0.8782 & 2.949 & 2.943 & 0.9631 & 0.93 & 0.1739 & 0.1622 & 0.9831 & 0.9811 & 1.653 & 1.626 \\
\hline 10 & Kothuru & 0.124 & 0.1202 & 0.876 & 0.8798 & 2.919 & 2.949 & 0.9923 & 0.9631 & 0.1846 & 0.1739 & 0.973 & 0.9831 & 1.677 & 1.653 \\
\hline
\end{tabular}

Table.8 Biodiversity Indices of Pathogenic bacteria in Well water in rainy season

\begin{tabular}{|c|c|c|c|c|c|c|c|c|c|c|c|c|c|c|c|}
\hline \multirow{3}{*}{$\begin{array}{l}\text { S. } \\
\text { No }\end{array}$} & \multirow{3}{*}{$\begin{array}{l}\text { Name of } \\
\text { Panchayath }\end{array}$} & \multicolumn{14}{|c|}{ Index } \\
\hline & & \multicolumn{2}{|c|}{ Simpson Index } & \multicolumn{2}{|c|}{$\begin{array}{l}\text { Dominance } \\
\text { Index }\end{array}$} & \multicolumn{2}{|c|}{$\begin{array}{l}\text { Shannon } \\
\text { Index }\end{array}$} & \multicolumn{2}{|c|}{$\begin{array}{l}\text { Menhinick } \\
\text { Index }\end{array}$} & \multicolumn{2}{|c|}{$\begin{array}{c}\text { Berger-Parker } \\
\text { Dominance Index }\end{array}$} & \multicolumn{2}{|c|}{$\begin{array}{l}\text { Equitability } \\
\text { Index }\end{array}$} & \multicolumn{2}{|c|}{$\begin{array}{c}\text { Margalef } \\
\text { Richness Index }\end{array}$} \\
\hline & & 1 & 2 & 1 & 2 & 1 & 2 & 1 & 2 & 1 & 2 & 1 & 2 & 1 & 2 \\
\hline 1 & Borra & 0.1198 & 0.1218 & 0.8802 & 0.8798 & 2.954 & 2.949 & 0.9631 & 0.9631 & 0.1739 & 0.1739 & 0.9848 & 0.9831 & 1.653 & 1.653 \\
\hline 2 & Tokkuru & - & - & - & - & - & - & - & - & - & - & - & - & - & - \\
\hline 3 & Valasi & 0.4097 & 0.1862 & 0.5903 & 0.8138 & 1.742 & 2.55 & 0.1306 & 0.2765 & 0.58 & 0.2569 & 0.5805 & 0.8499 & 0.8506 & 1.04 \\
\hline 4 & Gumma & - & - & - & - & - & - & - & - & - & - & - & - & - & - \\
\hline 5 & Pedabidda & 0.1236 & 0.1226 & 0.8764 & 0.8774 & 2.922 & 2.929 & 0.9923 & 0.9774 & 0.1846 & 0.1791 & 0.974 & 0.9762 & 1.677 & 1.665 \\
\hline 6 & Kondiba & 0.1232 & 0.1221 & 0.8768 & 0.8779 & 2.964 & 2.975 & 0.7428 & 0.7243 & 0.1724 & 0.1639 & 0.9881 & 0.9916 & 1.473 & 1.457 \\
\hline 7 & Garugubilli & - & - & - & - & - & - & - & - & - & - & - & - & - & - \\
\hline 8 & Gumma kota & 0.1216 & 0.1248 & 0.8784 & 0.8752 & 2.977 & 2.958 & 0.7303 & 0.7127 & 0.1667 & 0.1746 & 0.9924 & 0.9859 & 1.462 & 1.447 \\
\hline 9 & Bheempolu & 0.1248 & 0.1279 & 0.8752 & 0.8721 & 2.958 & 2.943 & 0.7127 & 0.7044 & 0.1746 & 0.1938 & 0.9859 & 0.981 & 1.447 & 1.44 \\
\hline
\end{tabular}


Table.9 Biodiversity Indices of Pathogenic bacteria in Steam water (unprotected) in winter season

\begin{tabular}{|c|c|c|c|c|c|c|c|c|c|c|c|c|c|c|c|}
\hline \multirow{3}{*}{$\begin{array}{l}\text { S. } \\
\text { No }\end{array}$} & \multirow{3}{*}{$\begin{array}{l}\text { Name of } \\
\text { Panchayath }\end{array}$} & \multicolumn{14}{|c|}{ Index } \\
\hline & & \multicolumn{2}{|c|}{ Simpson Index } & \multicolumn{2}{|c|}{$\begin{array}{l}\text { Dominance } \\
\text { Index }\end{array}$} & \multicolumn{2}{|c|}{$\begin{array}{l}\text { Shannon } \\
\text { Index }\end{array}$} & \multicolumn{2}{|c|}{$\begin{array}{l}\text { Menhinick } \\
\text { Index }\end{array}$} & \multicolumn{2}{|c|}{$\begin{array}{c}\text { Berger-Parker } \\
\text { Dominance Index }\end{array}$} & \multicolumn{2}{|c|}{$\begin{array}{l}\text { Equitability } \\
\text { Index }\end{array}$} & \multicolumn{2}{|c|}{$\begin{array}{c}\text { Margalef } \\
\text { Richness Index }\end{array}$} \\
\hline & & 1 & 2 & 1 & 2 & 1 & 2 & 1 & 2 & 1 & 2 & 1 & 2 & 1 & 2 \\
\hline 1 & Borra & 0.1195 & 0.1268 & 0.8805 & 0.8732 & 2.915 & 2.88 & 1.249 & 1.249 & 0.2195 & 0.2439 & 0.9716 & 0.9598 & 1.885 & 1.885 \\
\hline 2 & Tokkuru & 0.1163 & 0.1318 & 0.8837 & 0.8682 & 2.939 & 2.858 & 1.206 & 1.143 & 0.2045 & 0.2041 & 0.9796 & 0.9527 & 1.85 & 1.799 \\
\hline 3 & Valasi & 0.2134 & 0.1738 & 0.7866 & 0.8262 & 2.437 & 2.699 & 0.1617 & 0.1286 & 0.337 & 0.2519 & 0.8124 & 0.8998 & 0.8971 & 0.8474 \\
\hline 4 & Gumma & 0.1195 & 0.1266 & 0.8805 & 0.8734 & 2.912 & 2.88 & 1.249 & 1.234 & 0.2195 & 0.2381 & 0.9706 & 0.9601 & 1.885 & 1.873 \\
\hline 5 & Pedabidda & 0.1349 & 0.1478 & 0.8651 & 0.8522 & 2.843 & 2.792 & 1.12 & 1.109 & 0.1961 & 0.2692 & 0.9478 & 0.9306 & 1.78 & 1.772 \\
\hline 6 & Kondiba & 0.1516 & 0.1519 & 0.8484 & 0.8481 & 2.772 & 2.767 & 1.089 & 1.069 & 0.2593 & 0.25 & 0.9242 & 0.9223 & 1.755 & 1.739 \\
\hline 7 & Garugubilli & 0.1479 & 0.1332 & 0.8521 & 0.8668 & 2.795 & 2.882 & 1.06 & 0.9923 & 0.2456 & 0.2154 & 0.9317 & 0.9607 & 1.731 & 1.677 \\
\hline 8 & Gumma kota & 0.1332 & 0.1218 & 0.8668 & 0.8782 & 2.882 & 2.949 & 0.9923 & 0.93 & 0.2154 & 0.1622 & 0.9607 & 0.9829 & 1.677 & 1.626 \\
\hline 9 & Bheempolu & 0.1228 & 0.1232 & 0.8772 & 0.8768 & 2.954 & 2.952 & 0.8944 & 0.8835 & 0.2 & 0.1951 & 0.9846 & 0.984 & 1.597 & 1.588 \\
\hline 10 & Kothuru & 0.1223 & 0.1222 & 0.8777 & 0.8778 & 2.958 & 2.958 & 0.8627 & 0.8729 & 0.186 & 0.1905 & 0.986 & 0.986 & 1.571 & 1.58 \\
\hline
\end{tabular}

Table.10 Biodiversity Indices of Pathogenic bacteria in tap water (protected stream) in winter season

\begin{tabular}{|c|c|c|c|c|c|c|c|c|c|c|c|c|c|c|c|}
\hline \multirow{3}{*}{$\begin{array}{l}\text { S. } \\
\text { No }\end{array}$} & \multirow{3}{*}{$\begin{array}{c}\text { Name of } \\
\text { Panchayath }\end{array}$} & \multicolumn{14}{|c|}{ Index } \\
\hline & & \multicolumn{2}{|c|}{ Simpson Index } & \multicolumn{2}{|c|}{$\begin{array}{l}\text { Dominance } \\
\text { Index }\end{array}$} & \multicolumn{2}{|c|}{$\begin{array}{l}\text { Shannon } \\
\text { Index }\end{array}$} & \multicolumn{2}{|c|}{$\begin{array}{l}\text { Menhinick } \\
\text { Index }\end{array}$} & \multicolumn{2}{|c|}{$\begin{array}{c}\text { Berger-Parker } \\
\text { Dominance Index }\end{array}$} & \multicolumn{2}{|c|}{$\begin{array}{l}\text { Equitability } \\
\text { Index }\end{array}$} & \multicolumn{2}{|c|}{$\begin{array}{c}\text { Margalef } \\
\text { Richness Index }\end{array}$} \\
\hline & & 1 & 2 & 1 & 2 & 1 & 2 & 1 & 2 & 1 & 2 & 1 & 2 & 1 & 2 \\
\hline 1 & Borra & 0.1163 & 0.1243 & 0.8837 & 0.8757 & 2.982 & 2.946 & 0.93 & 0.8781 & 0.1622 & 0.1928 & 0.9939 & 0.982 & 1.626 & 1.584 \\
\hline 2 & Tokkuru & 0.1251 & 0.1251 & 0.8749 & 0.8749 & 2.949 & 2.947 & 0.8251 & 0.8433 & 0.1915 & 0.2 & 0.9829 & 0.9823 & 1.541 & 1.556 \\
\hline 3 & Valasi & - & - & - & - & - & - & - & - & - & - & - & - & - & - \\
\hline 4 & Gumma & - & - & - & - & - & - & - & - & - & - & - & - & - & - \\
\hline 5 & Pedabidda & - & - & - & - & - & - & - & - & - & - & - & - & - & - \\
\hline 6 & Kondiba & - & - & - & - & - & - & - & - & - & - & - & - & - & - \\
\hline 7 & Garugubilli & - & - & - & - & - & - & - & - & - & - & - & - & - & - \\
\hline 8 & Gumma kota & 0.1257 & 0.1251 & 0.8743 & 0.8749 & 2.946 & 2.949 & 0.8 & 0.8251 & 0.18 & 0.1915 & 0.9822 & 0.9829 & 1.52 & 1.541 \\
\hline 9 & Bheempolu & - & - & - & - & - & - & - & - & - & - & - & - & - & - \\
\hline 10 & Kothuru & - & - & - & - & - & - & - & - & - & - & - & - & - & - \\
\hline
\end{tabular}


Table.11 Biodiversity Indices of Pathogenic bacteria in Bore water in winter season

\begin{tabular}{|c|c|c|c|c|c|c|c|c|c|c|c|c|c|c|c|}
\hline \multirow{3}{*}{$\begin{array}{l}\text { S. } \\
\text { No }\end{array}$} & \multirow{3}{*}{$\begin{array}{l}\text { Name of } \\
\text { Panchayath }\end{array}$} & \multicolumn{14}{|c|}{ Index } \\
\hline & & \multicolumn{2}{|c|}{ Simpson Index } & \multicolumn{2}{|c|}{$\begin{array}{l}\text { Dominance } \\
\text { Index }\end{array}$} & \multicolumn{2}{|c|}{$\begin{array}{l}\text { Shannon } \\
\text { Index }\end{array}$} & \multicolumn{2}{|c|}{$\begin{array}{l}\text { Menhinick } \\
\text { Index }\end{array}$} & \multicolumn{2}{|c|}{$\begin{array}{c}\text { Berger-Parker } \\
\text { Dominance Index }\end{array}$} & \multicolumn{2}{|c|}{$\begin{array}{l}\text { Equitability } \\
\text { Index }\end{array}$} & \multicolumn{2}{|c|}{$\begin{array}{c}\text { Margalef } \\
\text { Richness Index }\end{array}$} \\
\hline & & 1 & 2 & 1 & 2 & 1 & 2 & 1 & 2 & 1 & 2 & 1 & 2 & 1 & 2 \\
\hline 1 & Borra & - & - & - & - & - & - & - & - & - & - & - & - & - & - \\
\hline 2 & Tokkuru & 0.1193 & 0.123 & 0.8807 & 0.877 & 2.929 & 2.912 & 1.167 & 1.167 & 0.1915 & 0.2128 & 0.9764 & 0.9708 & 1.818 & 1.818 \\
\hline 3 & Valasi & 0.3216 & 0.2814 & 0.6784 & 0.7186 & 1.842 & 2.046 & 0.171 & 0.1858 & 0.4228 & 0.3641 & 0.6141 & 0.6819 & 0.9102 & 0.9302 \\
\hline 4 & Gumma & 0.1351 & 0.1223 & 0.8649 & 0.8777 & 2.841 & 2.916 & 1.167 & 1.155 & 0.2128 & 0.2083 & 0.9469 & 0.9722 & 1.818 & 1.808 \\
\hline 5 & Pedabidda & 0.1322 & 0.1295 & 0.8678 & 0.8705 & 2.858 & 2.866 & 1.131 & 1.167 & 0.2 & 0.2128 & 0.9526 & 0.9552 & 1.789 & 1.818 \\
\hline 6 & Kondiba & 0.1202 & 0.1328 & 0.8798 & 0.8672 & 2.929 & 2.865 & 1.089 & 1.099 & 0.1852 & 0.2264 & 0.9763 & 0.9551 & 1.755 & 1.763 \\
\hline 7 & Garugubilli & 0.1328 & 0.1162 & 0.8672 & 0.8838 & 2.865 & 2.96 & 1.099 & 1.069 & 0.2264 & 0.1786 & 0.9551 & 0.9866 & 1.763 & 1.739 \\
\hline 8 & Gumma kota & 0.1393 & 0.1202 & 0.8607 & 0.8798 & 2.826 & 2.929 & 1.099 & 1.089 & 0.2264 & 0.1852 & 0.942 & 0.9763 & 1.763 & 1.755 \\
\hline 9 & Bheempolu & 0.1258 & 0.1403 & 0.8742 & 0.8597 & 2.887 & 2.814 & 1.167 & 1.109 & 0.1915 & 0.2308 & 0.9622 & 0.9379 & 1.818 & 1.772 \\
\hline 10 & Kothuru & 0.1258 & 0.1351 & 0.8742 & 0.8649 & 2.892 & 2.841 & 1.167 & 1.167 & 0.2128 & 0.2128 & 0.9641 & 0.9469 & 1.818 & 1.818 \\
\hline
\end{tabular}

Table.12 Biodiversity Indices of Pathogenic bacteria in Well water in winter season

\begin{tabular}{|c|c|c|c|c|c|c|c|c|c|c|c|c|c|c|c|}
\hline \multirow{3}{*}{$\begin{array}{l}\text { S. } \\
\text { No }\end{array}$} & \multirow{3}{*}{$\begin{array}{l}\text { Name of } \\
\text { Panchayath }\end{array}$} & \multicolumn{14}{|c|}{ Index } \\
\hline & & \multicolumn{2}{|c|}{ Simpson Index } & \multicolumn{2}{|c|}{$\begin{array}{l}\text { Dominance } \\
\text { Index }\end{array}$} & \multicolumn{2}{|c|}{$\begin{array}{l}\text { Shannon } \\
\text { Index }\end{array}$} & \multicolumn{2}{|c|}{$\begin{array}{l}\text { Menhinick } \\
\text { Index }\end{array}$} & \multicolumn{2}{|c|}{$\begin{array}{c}\text { Berger-Parker } \\
\text { Dominance Index }\end{array}$} & \multicolumn{2}{|c|}{$\begin{array}{l}\text { Equitability } \\
\text { Index }\end{array}$} & \multicolumn{2}{|c|}{$\begin{array}{c}\text { Margalef } \\
\text { Richness Index }\end{array}$} \\
\hline & & 1 & 2 & 1 & 2 & 1 & 2 & 1 & 2 & 1 & 2 & 1 & 2 & 1 & 2 \\
\hline 1 & Borra & 0.1162 & 0.123 & 0.8838 & 0.877 & 2.96 & 2.911 & 1.069 & 1.089 & 0.1786 & 0.1852 & 0.9866 & 0.9702 & 1.739 & 1.755 \\
\hline 2 & Tokkuru & - & - & - & - & - & - & - & - & - & - & - & - & - & - \\
\hline 3 & Valasi & 0.2227 & 0.3813 & 0.7773 & 0.6187 & 2.298 & 1.745 & 0.1319 & 0.1711 & 0.2649 & 0.5146 & 0.7659 & 0.5818 & 0.8525 & 0.9103 \\
\hline 4 & Gumma & - & - & - & - & - & - & - & - & - & - & - & - & - & - \\
\hline 5 & Pedabidda & 0.123 & 0.1351 & 0.877 & 0.8649 & 2.912 & 2.841 & 1.167 & 1.167 & 0.2128 & 0.2128 & 0.9708 & 0.9469 & 1.818 & 1.818 \\
\hline 6 & Kondiba & 0.1154 & 0.1232 & 0.8846 & 0.8768 & 2.988 & 2.952 & 0.9177 & 0.8835 & 0.1579 & 0.1951 & 0.9961 & 0.984 & 1.616 & 1.588 \\
\hline 7 & Garugubilli & - & - & - & - & - & - & - & - & - & - & - & - & - & - \\
\hline 8 & Gumma kota & - & - & - & - & - & - & - & - & - & - & - & - & - & - \\
\hline 9 & Bheempolu & 0.1179 & 0.1198 & 0.8821 & 0.8802 & 2.977 & 2.967 & 0.9058 & 0.9001 & 0.1795 & 0.1772 & 0.9925 & 0.9889 & 1.607 & 1.602 \\
\hline 10 & Kothuru & 0.1163 & 0.1243 & 0.8837 & 0.8757 & 2.982 & 2.946 & 0.93 & 0.8781 & 0.1622 & 0.1928 & 0.9939 & 1.584 & 1.626 & 0.982 \\
\hline
\end{tabular}


Both Menhinick's and Margalef's indices measure species richness in an ecosystem. Menhinick's index values were found to be almost similar in all the panchaths except in Valasi panchayath and their species richness. Margalef index (Margalef, 1958) relates the number of species to total number of individuals. The fall in the value of Margalef index shows the rise in the level of pollution. Margalef index value showed increasing trend conforming the minimum level of pollution. Mukherjee (1997) reported that higher species richness $\left(\mathrm{R}_{1}\right.$ and $R_{2}$ ) is characterized by larger food chain. The higher value of Shannon's index $\left(H^{\prime}\right)$ indicates Greater Species Diversity. The Greater species diversity means larger food chain and more cases of inter-specific interactions and greater possibilities for the negative feedback control which reduces oscillations and hence increases the stability of the community (Ludwick and Reynold, 1998)

Pielou's evenness index (E) (1967) status that species evenness is a measure of diversity that quantifies how equal the community is numerically. The index $\mathrm{E}$ is a constraint between 1 and 1 . Frequent variation in communication between the species the higher the value of $\mathrm{E}$. The $\mathrm{E}$ values of reservoirs were higher which were near to one. Evenness indices indicate whether all species in a sample are equally abundant. This means that species evenness decreased with increasing size of the bacterial population. Equitability (evenness) was relatively high during the raining season indicating a reduction in the bacterial diversity at this period (Shinde et al., 2011; Adesalu and Nwankwo, 2008). BergerParker dominant index (1970) is the number of individuals in the dominant taxon divided by number of individual (n). It is the largest species proportion of all species in a community. This index is most strongly influenced by evenness of the indices (Shannon and Wiener, 1949). Its reciprocal value is an index of diversity. Berger-Parker Dominance index was higher in Valasi panchayath than other 9 panchayths.

Various diversity measures have potential application in aquatic ecosystem, mainly in conservation. It is often understood that species rich communities are better than species poor communities. Secondly, in environmental monitoring, it is assumed that the adverse effect of pollution will be reflected in the reduction of diversity or change in the composition of species abundance. Both these factors involve diversity as an index of good ecosystem. Roseberg (1976) and Patrick (1973) are of the opinion that enriched or polluted ecosystem displays a reduction in diversity. Shannon and Wiener index is widely accepted in pollution monitoring. Platt et al. (1984) used the Simpson's index in bio monitoring. Stoermer (1984) discussed the role of the phytoplanton species and assembling as bio-indicators. Sample species richness and dominance measure are invariably informative. There is considerable evidence that conversation strategies may be improved if information on species abundance patterns is taken in to account. Maguran (1983) comment that ecologist should be able to ask the question and formulate the hypothesis to help them understand and sensitively manage the natural ecosystem. According to diversity indices, Valasi Panchayth (Bore and well water samples) were polluted rest water samples were unpolluted regarding the quality of water.

\section{References}

Adesalu, T.A. and Nwankwo, D.I. 2008. Effect of water quality indices on phytoplankton of a sluggish tidal 
creek in Lagos, Nigeria. Pak. J. Biol. Sci., 11: 836-844.

Akar, B. and Sahin, B. 2006. Benthic algal flora of Karranlik lake and diversity of epipelic algae. Fresen. Environ. Bul., 15: 48-54.

Berger, W.H. and Parker, F.L. 1970. Diversity of planktonic foraminifera in deep-sea sediments. Sci., 168: 1345-1347.

Caruso, T., Pigino, G., Bernini, F., Bargagli, R., Migliorini, M. 2007. The BergerParker index as an effective tool for monitoring the biodiversity of disturbed soils: a case study on Mediterranean oribatid (Acari: Oribatida) assemblages. Biodivers. Conserv., 16: 3277-3285.

Chang Tian, Xuetang lu, Haiyan Pei, Wenrong $\mathrm{Hu}$ and Jun Xie. 2013. Seasonal dynamics or Phytoplankton and its relationship with the environmental factors in Dongping Lake, China. Environ. Monit. Assess., 185: 2627-2645.

Gayathri, N., Rajashekhar, M., Kaneez Fatima, Vijaykumar, K., Ratandeep and Mahesh Baburrao. 2011. Hydrochemistry and Plankton Diversity Of Tungabhadra Reservoir Bellary District, Karnataka. Int. J. Zoo. Res., 1(1): 01-07.

Harris, G.P. 1986. Phytoplankton ecology; structure, function and fluctuation. Cambridge University Press. 384.

Hurlbert, S.H. 1971. The nonconcept of species diversity: a critique and alternative parameters. Ecol., 52: 577-586.

Ludwick, J.A., Reynolds, J.F. 1998. Statistical ecology a primer on methods and computing A WileyInterscience Publication. New York. 1-337.
Magurran, A.E. 2004. Measuring biological diversity. 2nd ed. Oxford, U.K: Blackwell Science Ltd.

Margalef, R. 1958. Information theory in ecology. Gen Syst., 3: 36-71.

Margalef, R. 1958. Information theory in ecology. Gen Syst., 3: 36-71.

Maria, M.G. 1993. Phytoplankton succession and diversity in a warm monomictic, relatively shallow lake: Lake Volvi, Macedonia, Greece. Hydrobiol., 249: 33-42.

May, R.M. 1975. Patterns of species abundance and diversity. In: Cody ML, Diamond JM, editors. Ecology and evolution of communities. Cambridge, MA: Harvard Univ. Press; pp. 81-120.

McGrady-Steed, J., Harris P.M. and Mortin, P.J. 1997. Biodiversity regulated ecosystem predictability. Nature, 390: 162-165.

Patrick, R. 1973. Use of algae especially diatoms in the assessment of water quality. American society for testing and methods, Special technical publication, 528: 76-95.

Peet, R.K. 1974. The measurement of species diversity. Ann. Rev. Ecol. Syst., 5: 285-307.

Pielou, E.C. 1967. The use of information theory in the study of the diversity of biological pollutions, Proc. $5^{\text {th }}$ Berkeley Symp. Math. Stat. Prob., 4: 163-177.

Platt, T., Sathyendranath, S., Caverhill, C.M. and Lewins, M. 1988. Ocean primary production and available further algorithms for remote sensing. Deep Sea Res., 35: 855-879.

Purvis, A., Hector, A. 2000. Getting the measure of biodiversity. Nature, 405: 212-219.

Rosenberg, R. 1976. Benthic faunal dynamics during succession 
following pollution abatement in a Sedish Estuary. Okios, 27:414-27.

Sahin, B. 2004. Species composition and diversity of epipelicalhae in Catal Lake (Sebinkarahisar-Giresun, Turkey). Turk. J. Biol., 28: 103-109.

Shannon, C.E. and Weiner, V. 1949. A Mathematical theory of communication, University press, Illinois Urban. 101- 107.

Shinde, S.E., Pathan, T.S., Raut, K.S., and Sonawane, D.L. 2011. Studies on the Physicochemical Parameters and Correlation Coefficient of Harsoolsavangi Dam, District Aurangabad, India. Middle-East J. Sci. Res., 8(3): 544-554.

Sigee, D.C. 2004. Freshwater microbiology: diversity and dynamic interactions of microorganisms in the aquatic environment. Chichester. UK: Wiley.

Sigee, D.C. 2004. Freshwater microbiology: diversity and dynamic interaction of microorganism in the aquatic environment. Chichester. UK: Wiley.

Stirling, G., Wilsey, B., 2001. Empirical relationships between Species Richness, Evenness and Proportional Diversity. The American Naturalist, 158(3): 286-299.

Stirling, G., Wilsey, B., 2001. Empirical Relationships between Species
Richness, Evenness, and Proportional Diversity. The American Naturalist, 158(3): 286-299.

Tarakeshwar, S., Subhabrata, G and Tirthankar, M. 2011. Variations in phytoplankton diversity and its relation with physic chemical parameters of a semi lentic water body of Golapbag, West Bengal, India. Int. J. Curr. Res., (3): 53-55.

Vadrucci, M.R., Sabetta, L., Fiocca, A., Mazziotti, C., Silvesti, C., Cabrini, M., Guardiani, B., Konjka, E., Evangelopoulous, A., Koutsoubas, D. and Basset, A. 2008. Statistical evaluation of differences in phytoplankton richness and abundance as constained by environmental drivers in traditional waters of the Mediterranean basin. Aquatic Conservation Marine and Freshwater Ecosystems, 18: 88-104.

Whittaker, R.H. 1972. Evolution and measurement of species diversity. Taxon., 21: 213-251.

Wilhm, J.L. 1975. Biological indicators of pollution, [in:] River ecology, B. A.Whitton (ed.), Studies in Ecology, Vol. 2, Blackwell Sci. Publ., London. 375-402.

\section{How to cite this article:}

Sandhya Deepika, D., and Laxmi Sowmya, K. 2016. Bioindices of Bacterial Communities. Int.J.Curr.Microbiol.App.Sci. 5(12): 219-233. doi: http://dx.doi.org/10.20546/ijcmas.2016.512.024 